$10-2014$

\title{
Commentaries on the IAALS' Honoring Families Initiative White Paper
}

Barbara A. Babb

University of Baltimore School of Law, bbabb@ubalt.edu

Follow this and additional works at: http://scholarworks.law.ubalt.edu/all_fac

Cart of the Courts Commons, and the Family Law Commons

\section{Recommended Citation}

Commentaries on the IAALS' Honoring Families Initiative White Paper, 52 Fam. Ct. Rev. 639 (2014)

This Article is brought to you for free and open access by the Faculty Scholarship at ScholarWorks@University of Baltimore School of Law. It has been accepted for inclusion in All Faculty Scholarship by an authorized administrator of ScholarWorks@University of Baltimore School of Law. For more information, please contact snolan@ubalt.edu. 


\section{FAMILY COURT REVIEW An Interdisciplinary Journal

\author{
Volume 52 Number 4
} \\ October 2014}

Leading dialogue in family court research, policy and practice for more than half a century

Editorial Notes

October 2014 - Andrew Schepard and Robert E. Emery

\section{Perspectives}

Ensuring a Place for Family Court Services in the Family Court of the Future: Do or Die Linda Fieldstone

Shared Parenting and Never-Married Families - Solangel Maldonado

SPECIAL ISSUE: Commentary on IAALS' Honoring Families Initiative: Courts and Communities Helping Families in Transition Arising from Separation or Divorce

\section{Guest Editor's Introduction}

Commentaries on the IAALS' Honoring Families Initiative White Paper - Barbara A. Babb

\section{Commentaries}

Family Courts Are Here to Stay, So Let's Improve Them-Barbara A. Babb

Don't Forget the Children: Court Protection from Parental Conflict is in the Best Interests of Children - Milfred D. Dale

An Appeal for Autonomy, Access, and Accountability in Family Court Reform Efforts Gabrielle Davis, Nancy Ver Steegh, and Loretta Frederick

Self-Represented Litigants, the Courts, and the Legal Profession: Myths and Realities John M. Greacen

The Challenges of Family Court Service Reform - Peter Salem

Additional Articles

Assessing the Relationship between the Quality of Juvenile Dependency Hearings and Foster Care Placements - Stephanie Macgill and Alicia Summers

Parents Apart: Differences Between Unmarried and Divorcing Parents in Separated Families Maureen R. Waller and Allison Dwyer Emory

\section{The Book Shelf}

Book Review: Leonard Edwards' The Role of the Juvenile Court Judge: Practice and EthicsHon. Janice M. Rosa

\section{Student Notes}

Ignorance Is Not Bliss: Why States Should Adopt California's Independent Counsel Requirement for the Enforceability of Prenuptial Agreements - Sandra Kennedy

Insuring That Good Deeds Go Unpunished: Instituting State-Provided Malpractice Protection for Pro Bono Family Lawyers - Julianne Prisco 


\title{
COMMENTARIES ON THE IAALS' HONORING FAMILIES INITIATIVE WHITE PAPER
}

\author{
Barbara A. Babb
}

\begin{abstract}
Family courts are not likely to disappear, as they currently constiute the largest proportion of trial court hings in most states. It appears as though family courts have become an emergency room for family problems. Thus, we need to enhance our efforts to improve the family justice system. In order to revamp family courts most effectively, there must be a focus on the creation of unificd family courts that are grounded in therapeutic jurisprudence and the ecology of human dcvelopment. This famework allows for a more responsive and holistic approach to families legal and underlying nonlegal needs. The goal of a unified family court is to aim to improve the lives of famities and ehitdren through judicial action, informal conrt proccedings, altcriative dispute resolution, and the provision of appropriate social services.

Key Points for the Family Court Community:

- The need for family court reform

- An underlying theoretical foundation to gude the family court reform process

- Employing therapeutic jurisqudence to ensnre an tutcome that can positizely affect the liyes of the families and children involved in cach legal proceding

- Utilizing the ecolngy of human development to assist with obtaintng a holistic view of fanities" tegal and underyying nonleyal issues

- A blueptint to create a unified faniy court to provide an effective, efficient, comprehensive resolution to cach family.' dispute
\end{abstract}

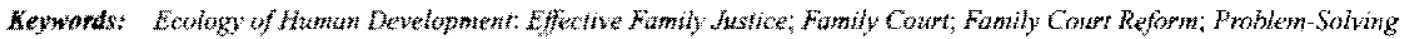

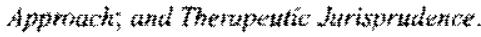

The July 2013 issue of Family Conrt Review (FCR) included a White Paper of the Institute for the Advancement of the American Legal System's (IAALS) Honoring Families Initiative on the court and separating and divorcing families. The White Paper presents alternatives to the traditional adjudication of family law disputes and proposes that other methods be available in communities to provide responsive and cost-effective resolutions to these matters. Noting the vital importance of planning for the future of children, the White Paper suggests a greater need for collaborative, interdisciplinary, and forward-looking systems, including mediation, parent education, early neutral evaluation, and a triage or differentiated case management process for sorting through various levels of family conflict it also emphasizes the importance of the community as a partner in thesc and other undertakings.

The White Paper highlights the devastating emotional and financial effects on children and families of resolving family law cases through the traditional adversarial process. It also details the escalating issues surrounding the increasing and substantial volume of self-represented famtly law litigants. The Whitc Paper notes many problems with existing family court systems that interfere with their ability to perform the core functions of the court. defined by the authors as protection, fact finding, and creating and enforcing orders. 
Although the White Paper suggests some reforms, including proposed principles needed to serve separating and divorcing families, the authors invite a response to three important questions: (1) Given shrinking court budgets, how should family courts be organized or reorganized? (2) Can the court's role in family disputes be restructured to allow the court to perform its core judicial functions more effectively? (3) What is the optimum method to organize and deliver essential mediation, education, legal, and therapeutic services? The White Paper issues a call to develop collectivcly the answers to these questions, and the authors of the commentaries described below provide their insights and responses.

Like the White Paper authors, I am a member of the Honoring Families Initiative Advisory Board. In my commentary that follows, I argue that family courts are not likely to disappear, as they currently constitute the largest proportion of trial court filings in most states. Because of this, and because family courts essentially have become an emergency room for family problems, we need to enhance our efforts to improve the family justice system. Indeed, many of the problems plaguing existing farnily courts, as highlighted in the White Paper, are impediments to the delivery of effective, efficient family justice. As I have advocated for quite some time, in order to truly revamp family courts, there needs to be a focus on uniffed family courts. These forums must strive explicitly to address farnilies' problems holistically and from a problem-solving approach and must ain to improve families' and children"s lives as a result of their involyement with the family justice system. Many of the elements that I believe are necessary components of a unified family court are those that the White Paper authors suggest as important reforms. As Maryland's former chief justice, Robert M. Bell. has stated eloquently and succinctly:

[W] have finally come to realize, that the effeetive resolution of legal disputes within a family requires a fundamental shift from the traditional adjudication focus to a more holistic. therapeutic model that attempts to improve the lives of farrilies and children in substantive ways. To achieve this new paradigm. thero must be a confuence of access to coordinated and comprehensive legal and social services. efficient case processing and management, and a more widely accessible court system, ${ }^{2}$

In his commentary, Dr. Milfred D. ("Bud") Dale supports many of the initiatives proposed in the White Paper. He identifies three fatal flaws that nced to be addressed in order to truly create informative. accessible, and responsive out-of-court dispute resolution models. He argues that we cannot ignore the child's view, as this perspcctive offers vital information for reaching an appropriate resolution. He also cautions that any reform measures must identify, recognize, and address the interests of high-conflict families and the need especially to protect children in these situations. He is less optimistic than the White Paper authors about the likelihood and effectiveness of communitybased dispute resolution efforts as substitutes for the family court. He wclcomes the encouragement of these community partnerships, but he cautions that they must not undermine or ignore the role of the court system in resolving family conflicts.

In the next commentary, Gabrielle Davis and Nancy Ver Steegh, both of whom are members of the Honoring Families Initiative Advisory Board along with Loretta Frederick agree with the White Paper's conclusion that an array of resolution alternatives should be available to those who can safely, knowingly, and responsibly benefit from them without the need to resort to judicial intervention. These authors caution, however, that families still must know that the traditional judicial process is available as a fair and predictable method to resolve family disputes. They also agree that family courts need to provide alternatiwe voluntary, fair, affordable, competent professional services in a manner that informs families and allows them affirmatively and knowingly to select a nethod best suited to their individual needs.

John Greacen is also a member of the Honoring Fanilies Initiative Advisory Board and is an expert on the needs of self-represented litigants and evaluations of programs to assist them. In his commentary, he addresses the White Paper's comments about self-represented litigants. He advocates for limited-scope legal representation and assures readers that most self-represented litigants do not choose to proceed without legal tepresentation. He also dispels what has become a myth - -that judges 
and court staff cannot assist self-represented litigants without violating their professional responsibility and ethical obligations. He suggests several strategies to ensure that self-represented litigants are treated fairly and have their legal issues resolved truly on the merits. Finally, he offers empirical evidence that undermines certain negative misconceptions about self-represented litigants.

Peter Salem, the final commentary author, is the executive director of AFCC and also a member of the Honoring Families Initiative Advisory Board. He commends the White Paper for emphasizing the importance of providing alternative dispute resolution methods. While he notes that providing community-based services in family law matters is a laudable goal, he believes it is impractical to suggest that these services be removed entirely from the court system. He discusses the differences, as well as the advantages and disadvantages, that may result from removing dispute resolution services entirely into the community.

I am very proud to be the guest editor for this Special Issue of $F C R$. I want to sincerely thank each of the commentary authors for these thoughtful, responsive, and engaging pieces. I also want to extend my gratitude to the White Paper authors for summarizing events that have transpired over the last many decades and that have significantly affected the lives of children and families, as well as the operation of family courts and the family dispute resolution process. The White Paper authors have provided much for all of $F C R$ 's readership to ponder, as there is a role for each of us to play as we continue to work to ensure that the family justice system is efficient, effective, and responsible for all children and families. It is time for all of us to respond.

\section{NOTES}

1. Rebecca Love Kourlis et al., LAAL' Honoring Fanilies Inituative: Courts and Communinies Helping Families in Transition Arising from Separation and Divorce, 5I FAM. CT. EV. 351 (2013).

2. Robert M. Bell, Administration of Justice. 32 MD. B.J. 2, 4 (1999).

Barbara A. Babb is an associale professor of law and the founder and director of the Sayra and Neil Meverhoff Center for Families, Children and the Courts at the University of Baltimore School of Law; where she has taught various family law: courses since 1989. Her interdisciplinary scholarship focuses on therapeutic jurisprudence, the ecology of hunan development. court reform in family law, and the creation of unified family courts. She has written and spoken extensively at the state, natwonal. and international levels, and she has participated in many court and law reform projects. She 2 s a member of the Editorial Advisory Boand of Family Court Review. She is a graduate of Cornell Law School and also holds an M.S. from Comell University and a B.S. from the Pennsylyania State University. 